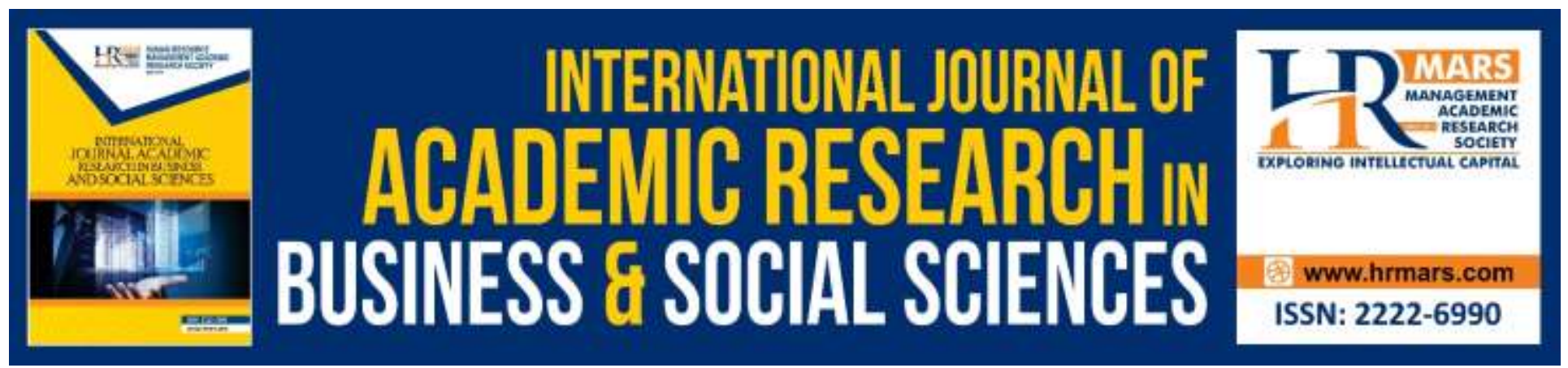

\title{
Determinants of Halal Food New Product Adoption Intention in Malaysia: A SmartPLS Approach
}

\author{
Bishr Altekreeti, Salina Daud
}

To Link this Article: http://dx.doi.org/10.6007/IJARBSS/v10-i5/7188

DOI:10.6007/IJARBSS/v10-i5/7188

Received: 12 March 2020, Revised: 14 April 2020, Accepted: 27 April 2020

Published Online: 09 May 2020

In-Text Citation: (Altekreeti \& Daud, 2020)

To Cite this Article: Altekreeti, B., \& Daud, S. (2020). Determinants of Halal Food New Product Adoption Intention in Malaysia: A SmartPLS Approach. International Journal of Academic Research in Business and Social Sciences, 10(5), 209-220.

\section{Copyright: (c) 2020 The Author(s)}

Published by Human Resource Management Academic Research Society (www.hrmars.com)

This article is published under the Creative Commons Attribution (CC BY 4.0) license. Anyone may reproduce, distribute, translate and create derivative works of this article (for both commercial and non-commercial purposes), subject to full attribution to the original publication and authors. The full terms of this license may be seen at: http://creativecommons.org/licences/by/4.0/legalcode

Vol. 10, No. 5, 2020, Pg. 209 - 220

http://hrmars.com/index.php/pages/detail/IJARBSS

JOURNAL HOMEPAGE

Full Terms \& Conditions of access and use can be found at http://hrmars.com/index.php/pages/detail/publication-ethics 


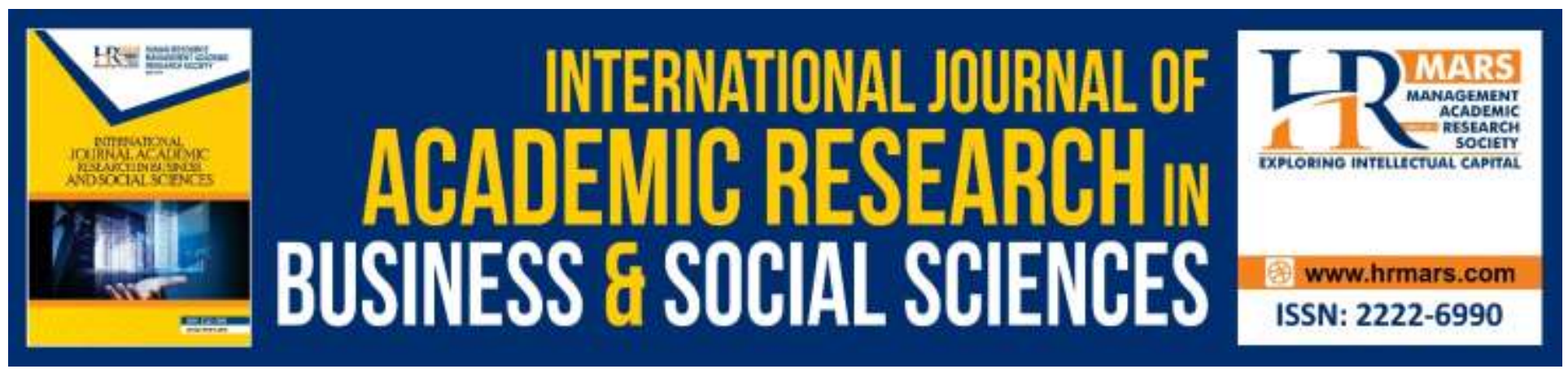

\title{
Determinants of Halal Food New Product Adoption Intention in Malaysia: A SmartPLS Approach
}

\author{
Bishr Altekreeti \\ College of Graduate Studies, Universiti Tenaga Nasional, Putrajaya, Malaysia \\ Email: Bisheralwaies@gmail.com
}

\section{Salina Daud}

College of Business Management and Accounting, Universiti Tenaga Nasional, Sultan Haji Ahmad Shah Campus, Muadzam Shah, Malaysia.

\begin{abstract}
The aim of this study is to examine the determinants of halal food new product adoption intention in Malaysia by extending the theory of planned behaviour (TPB). A quantitative research method has been adopted and a questionnaire survey has been distributed. Responses from 450 adult Muslims in Klang Valley, Malaysia were collected. Partial least squares structural equation modelling (PLSSEM) was applied to show that all factors, except subjective norm, had significantly influenced halal food new product adoption intention. For future research, the model can be adopted to investigate non-Muslims halal food new product adoption intention. Moreover, future research can broaden the study beyond Klang Valley. The practical implication for this research shows that the results of this study can be used as a strategy by any business that aims to compete in the halal market, especially businesses with newly launched products.
\end{abstract}

Keywords: Malaysia, Halal, Islam, Theory of Planned Behaviour, New Product Adoption.

\section{Introduction}

Food consumption in many cultures is governed by religious laws. In Islam, Muslims should only eat halal food (Sherwani, Ali, Ali, \& Hussain, 2018). Halal food refers to food which was made lawful to consume by Allah SWT and is mentioned in the Quran. For instance, in some Muslim-majority countries, like Malaysia, the halal concept constitutes daily food consumption a daily driver of food consumption. The Muslims in Malaysia do not buy any food product if the Halal certification is not applied on the product (Alam \& Sayuti, 2011).

The increase in awareness of the halal concept has caused substantial growth in the global market, whereby the halal market segment is approxamitely around US\$2.3 TN (Karoui \& Khemakhem, 2019). Moreover, the growing Muslim populace, which is projected to be 1.8 billion (Sherwani et al., 2018), considerably affects the halal market's size and demand. The Malaysian halal market is a prominent 
segment which contributes to the economic revenue of the country (Marmaya, Zakaria, \& Desa, 2019). Here, the demand for halal products is not restricted to the Muslim majority; instead, the nonMuslims are also acknowledging halal food as a healthy choice (Rezai, Mohamed, \& Shamsudin, 2012). Correspondingly, many food businesses are recognising the prospect of the halal market, which has motivated them to provide halal-certified food. It is reported that many businesses have seen an increase in their customer base once they standardized their menus to Halal (Ali, Xiaoling, Sherwani, \& Ali, 2017). Businesses are introducing halal certification to assure Muslims that the food they are selling complies with the Sharia laws. Additionally, it is to assure non-Muslims that the food is clean, safe, and hygienic (Elseidi, 2018; Rachbini, 2018).

Hence, the increase in the introduction of halal certification by businesses indicates that the halal market competition is increasing. However, businesses are venturing into the halal market without a clear understanding of how to influence consumer intention, which is crucial for long-term business profitability (Afendi, Azizan, \& Darami, 2014). Therefore, some businesses are setting their priorities towards encouraging consumers new product adoption intention (Zakaria, Majid, Jusoh, \& Zakaria, 2017). Nevertheless, factors which influence consumption behaviour is rather unclear. Despite the influence of religion on consumption behaviour, many other factors could influence halal food new product adoption intention, such as environmental and marketing stimuli (Karoui \& Khemakhem, 2019). To close this gap, the research intends to examine the factors that influence consumers' new product adoption intention. To the best of the authors' knowledge, previous research has not investigated the factors which influence halal food new product adoption intention in Malaysia. As such, the aim of this research is to examine the factors that influence halal food new product adoption intention in Malaysia. Thus, the theory of planned behaviour (TPB) has served as the theoretical background of this investigation. Furthermore, an attempt has been made to incorporate three extra constructs, which is relatively related to attracting consumers.

\section{Literature Review}

Ajzen (1985) proposed TPB as an extension of the theory of reasoned action (TRA) because of its limitation when dealing with volitional control (Rahim \& Junos, 2012). TPB has successfully measured many behaviours (Yang, Lee, \& Zo, 2017). Several studies have been successful in using TPB to evaluate food consumption behaviour (Ali et al., 2017), especially halal food purchase behaviour intention (Rachbini, 2018; Khan \& Azam, 2016). According to the theory, intention is, in general, a person's perception of a certain behaviour's performance (Jain, Khan, \& Mishra, 2017). The present research aims to study halal food new product adoption intention, which is the consumers' first interaction with the product that helps in evaluating the product. A new product adoption normally occurs with products that consumers are not familiar with (Sun, Zuo \& Kong, 2016). Understanding the determinants of new product adoption intention can aid marketers to build more efficient strategies (Afendi et al., 2014). Hence, this investigation is especially critical since with the recent market changes and halal products gaining momentum many consumers will adopt new halal products. Boyd (1972) has indicated that several factors could help attract consumers to new product adoption such as promotion. Therefore, alongside the TPB dimensions, three additional constructs that influence consumers to adoption new products are discussed. 


\section{Attitude}

Ajzen (1985) has stated that behavioural intention is ascertained using three predictors, namely attitude, subjective norm, and perceived behavioural control. Attitude is the psychological tendency which is conveyed by assessing a specific entity with a certain level of favour or disfavour (Bonne, Vermeir, \& Verbeke, 2008). According to TPB, attitude is affected by beliefs. In general, a person's likelihood to adopt a new halal food product is based on whether he or she believes that this action will yield a positive outcome. In Muslim societies, attitude concerning buying halal food is usually positive due to the influence of Islam on its followers to eat halal food (Bonne et al., 2008). As such, most investigations have reported that attitude is a prominent influencer of halal purchase intention (Vanany, Soon, Maryani, \& Wibawa, 2019; Sherwani et al., 2018). For instance, Alam and Sayuti (2011) utilised TPB to predict the buying of halal food in Malaysia and discovered that a positive attitude towards halal food positively influenced halal purchase intention. Similarly, Khalek and Ismail (2015) investigated generation Y's halal consumption behaviour using TPB and found that all its components positively influenced halal purchase intention. Thus, it is proposed that:

\section{H1. Attitude is a significant determinant for halal food new product adoption intention.}

\section{Subjective Norm}

According to TPB, subjective norm is also a predictor of behavioural intention. Subjective norm concerns the social pressure a person might perceive to perform certain behaviours (Ali et al., 2017). Under TPB, subjective norm is based on normative belief. Hence, an individual's likelihood to adopt a new halal food product is based on whether he or she believes that his or her social surroundings think it is a good idea. Past studies have indicated that subjective norm influences halal food purchase intention in collectivist and non-collectivist societies. For instance, Bonne et al. (2008) have examined the influence of religion on halal meat consumption in France, a country considered to have an individualist society. They discovered that subjective norm positively influenced the intention to consume halal meat. On the other hand, in a collectivist society, such as in Malaysia, Marmaya et al. (2019) reported that subjective norm also positively influenced halal food purchase intention. Therefore, this study proposed the following:

H2. Subjective norm is a significant determinant for halal food new product adoption intention.

\section{Perceived Behavioural Control}

Perceived behavioural control has been included as a means to extend TRA into TPB. It can be described as people's understanding of how easy or difficult executing the behaviour of interest is (Rahim \& Junos, 2012). Like attitude and subjective norm, perceived behaviour control is also based on belief, which is control belief. Accordingly, consumers' likelihood to adopt a new halal food product depends on whether they believe that they can control this behaviour. Although past studies have accurately predicted halal purchase behaviour using TRA (Mukhtar \& Butt, 2012; Lada, Tanakinjal \& Amin, 2009), other studies determined that perceived behavioural control also positively influenced halal food purchase behaviour and intention. For instance, Khalek (2014) examined young Malaysian consumers' attitude towards halal food outlets and discovered that perceived behavioural control was a significant predictor for young consumers' attitude. Similarly, Khalek and Ismail (2015) indicated in their investigation that perceived behavioural control portrayed a significant role in predicting intention to purchase halal food. Hence, the following is proposed: 
INTERNATIONAL JOURNAL OF ACADEMIC RESEARCH IN BUSINESS AND SOCIAL SCIENCES Vol. 10, No. 5, May, 2020, E-ISSN: 2222-6990 @ 2020 HRMARS

H3. Perceived behavioural control is a significant determinant for halal food new product adoption intention.

\section{Halal Certification}

The increase in incidents, where consumers find questionable or non-halal ingredients in food, has raised the demand for halal certification. This certification is a significant symbol for Muslims to assure them that what they are consuming is halal (Talib, Sarawi, Hamid, \& Chin, 2016). Additionally, halal certification asserts that it meets quality standards, which can boost consumers' intention to adopt new halal food products (Abdul, Ismail, Hashim, \& Johari, 2009; Mohayidin \& Kamarulzaman, 2014). Muslims in Malaysia frequently inspect products halal certification when they intend to adopt new halal food products (Alam \& Sayuti, 2011). According to past literature, halal certification exerts a positive significant influence on halal purchase behaviour. For instance, in a recent study by Hakeem and Lee (2018), they studied consumers' attitude towards Korean street food. They found that halal certification is a critical predictor of consumer behaviour. Moreover, Awan, Siddiquei and Haider (2015), who investigated determinants of halal food purchase intention, indicated that halal certification had a positive significant relationship with halal food purchase intention. Thus, it is proposed that:

H4. Halal certification is a significant determinant for halal food new product adoption intention.

\section{Health Consciousness}

One of the rising concerns in Malaysia is food health and safety. Halal food is considered safer, cleaner, and more hygienic than non-halal food because a holder of halal certification must follow Sharia laws to label the food as halal. Hence, the whole halal supply chain must follow certain regulations that wholesome standards (Ngah, Zainuddin, \& Thurasamy, 2017; Haque, Sarwar, Yasmin, Tarofder, \& Hossain, 2015). Thus, eating halal food is no longer just an Islamic obligation (Bashir, Kin, Mohibbulah, Shon, \& Choi, 2018). Even non-Muslims are accepting halal food because of the awareness that it is wholseome (Rezai et al., 2012). Accordingly, many studies have suggested that health consciousness influence halal food consumption and demand. Bonne et al. (2008), for example, mentioned that health-conscious Muslim consumers in Europe have a higher intention to consume halal meat. Likewise, Hussain, Rahman, Zaheer and Saleem (2016) have suggested that health consciousness positively influences halal food purchase intention. Therefore, the study has suggested the following hypothesis:

H5. Health consciousness is a significant determinant for halal food new product adoption intention.

\section{Promotion}

Promotion is one of the prominent market forces which is part of the marketing mix (Kotler \& Keller, 2012). It should be included in all marketing strategies that aim to attract new consumers (Aziz \& Chok, 2013; Atulkar \& Kesari, 2017). Many consumers choose to adopt new products that offer promotions (Chuah, Marimuthu, Kandampully, \& Bilgihan, 2017). For example, Malaysian consumers are found to be attracted to products that offers promotions as it provides utilitarian and hedonic benefits (Weng \& Run, 2013). With the increase in Halal businesses competition around the globe, many businesses are trying to differentiate their products from that of their competitors to attract 
INTERNATIONAL JOURNAL OF ACADEMIC RESEARCH IN BUSINESS AND SOCIAL SCIENCES Vol. 10, No. 5, May, 2020, E-ISSN: 2222-6990 @ 2020 HRMARS

consumers (Ali, Xiaoloing, Sherwani \& Ali, 2018). Promotions can help businesses achieve a competitive edge over their competitors (Aziz \& Chok, 2013). It is reported in the literature that promotions influence purchase decision and intention. For instance, Arsil, Tey, Brindal, Phua and Liana (2018) have mentioned that consumers in Malaysia tend to search for promotions while grocery shopping. Besides that, in an empirical study by Aziz and Chok (2013), they have indicated that promotions influence intention to purchase halal food products amongst Malaysia's non-Muslims. As such, the following is suggested:

H6. Promotion is a significant determinant for halal food new product adoption intention.

\section{Study's Framework}

According to the literature review several hypotheses has been made. As such, based on the hypotheses, this research has suggested a framework based on TPB and added three additional variables, as presented in Figure 1. The figure illustrates halal food new product adoption intention as an endogenous construct and the six exogenous constructs which determine halal food new product adoption intention.

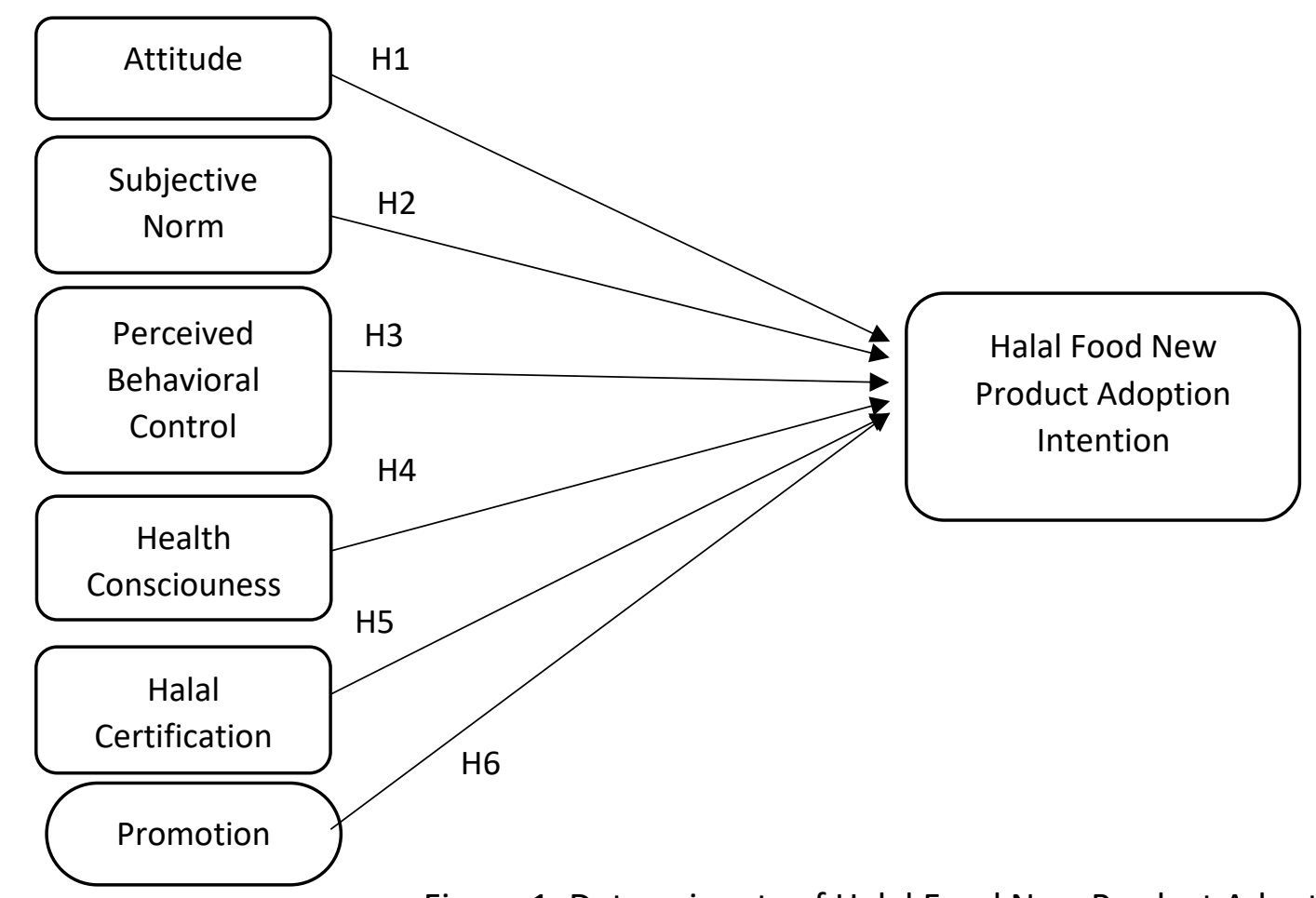

Figure 1. Determinants of Halal Food New Product Adoption Intention

\section{Research Methodology Measurement}

The study's measurements were adopted from past research after reviewing the literature. The questionnaire had two sections, namely the first section which contained the measurements for the constructs and the second section that was developed to collect demographic information. The first 
section comprised measurements regarding halal food new product adoption intention, attitude, subjective norm, perceived behavioural control, halal certification, health consciousness, and promotion. These measurements were adapted from Lada et al. (2009), Bonne et al. (2008), Awan et al. (2015), Al-Swidi, Huque, Hafeez and Shariff (2014), Aziz and Chock (2013), and Yasanallah and Vahid (2012). The questionnaire was based on a Likert scale of $1=$ strongly disagree to $5=$ strongly agree. Furthermore, a pilot test was performed with 45 samples. Based on the pilot study's results, two questions were removed due to lack of validity.

\section{Sample}

The data were gathered from questionnaires (not including the pilot study) distributed in Klang Valley, Malaysia. From the 450 questionnaires distributed, only 400 were returned. The collected responses were subjected to data screening and were examined for outliers and incomplete responses. Consequently, 55 responses, which were considered as incomplete responses were removed; hence, 345 responses remained. The data set was created in SPSS version 23.0 and using SmartPLS 3.2.9, the data were analysed.

\section{Results and Discussion}

The study opted for partial least squares structural equation modelling (PLS-SEM) rather than Covariance Based Structural Equation modelling (CB-SEM) due to several reasons. Firstly, PLS-SEM is not concerned with data normality. Next, PLS-SEM supports model complexity. Finally, PLS-SEM can work with both large and small sample sizes (Hair, Risher, Sarstedt, \& Ringle, 2019). Thus, a two-stage analytical procedure suggested in PLS-SEM was chosen. In the first stage, the measurement model was tested, including the measurements' reliability and validity. In the following stage, the structural model was examined, which was mainly testing the hypotheses. Concerning respondents $(n=345)$, male and female respondents comprised $54 \%$ and $46 \%$, respectively. Most respondents were Malays (80\%), while the rest were from other ethnicities (20\%). Moreover, all the respondents were Muslims. Regarding age, most were in the $41-50$ years old (35.5\%) category, followed by above 50 years old (22\%) and $21-30$ years old (20\%). Most of them had a good income while only 30 respondents had a low income.

\section{Measurement Model}

The analysis of the measurement model was done to test the construct reliability and construct validity. Composite reliability (CR) was employed to test construct reliability (Hair, Sarstedt, Hopkins, \& Kuppelwieser, 2014). The recommended value for internal consistency reliability is above 0.7 (Henseler, Ringle, \& Sinkovics, 2009). On the other hand, construct validity was done by assessing convergent and discriminant validity. To check for convergent validity, the average variance extracted (AVE) was tested with a cut-off point of 0.5 . For discriminant validity, the study used heterotraitmonotrait ratio (HTMT). According to Henseler, Ringle and Sarstedt (2015), HTMT is more appropriate to check for discriminant validity than cross-loading and Fornell-Larcker criterion as it is found to be more reliable. Accordingly, the discriminant validity between two constructs will be established if the HTMT value is lower than 0.90 . This study's results for reliability and validity are shown in Tables 1 and 2. All the reliability values of CR were more than the suggested value of 0.7 , whereas all the convergent validity values were more than 0.5 (Table 1). Meanwhile, for discriminant validity, the values were lower than 0.90 , indicating that discriminant validity was met (Table 2 ). 
INTERNATIONAL JOURNAL OF ACADEMIC RESEARCH IN BUSINESS AND SOCIAL SCIENCES Vol. 10, No. 5, May, 2020, E-ISSN: 2222-6990 @ 2020 HRMARS

Table 1: Reliability and convergent validity results

\begin{tabular}{|l|l|l|}
\hline Construct & CR & AVE \\
\hline ATT & 0.951 & 0.828 \\
\hline HC & 0.938 & 0.715 \\
\hline HLOG & 0.886 & 0.660 \\
\hline PBC & 0.935 & 0.782 \\
\hline PRO & 0.949 & 0.824 \\
\hline PAI & 0.897 & 0.686 \\
\hline SN & 0.906 & 0.708 \\
\hline
\end{tabular}

Note: Attitude (ATT); Health Consciousness (HC); Halal Certification (HLOG); Perceived Behavioural Control (PBC); Promotion (PRO); Halal Food New Product Adoption Intention (PAI); and Subjective Norm (SN).

Table 2: Discriminant validity results

\begin{tabular}{|l|l|l|l|l|l|l|l|}
\hline & ATT & HC & HLOG & PBC & PRO & PTI & SN \\
\hline ATT & & & & & & & \\
\hline HC & 0.062 & & & & & & \\
\hline HLOG & 0.099 & 0.687 & & & & & \\
\hline PBC & 0.131 & 0.528 & 0.707 & & & & \\
\hline PRO & 0.191 & 0.500 & 0.654 & 0.741 & & & \\
\hline PTI & 0.197 & 0.615 & 0.737 & 0.691 & 0.706 & & \\
\hline SN & 0.029 & 0.061 & 0.067 & 0.063 & 0.067 & 0.111 & \\
\hline
\end{tabular}

Note: Attitude (ATT); Health Consciousness (HC); Halal Certification (HLOG); Perceived Behavioural Control (PBC); Promotion (PRO); Halal Food New Product Adoption Intention (PAI); and Subjective Norm (SN).

\section{Multi-collinearity}

Before proceeding with the structural model analysis, the study checked if there was any issue of collinearity among the constructs and if the affected constructs must be combined or deleted. Multicollinearity is described as a high correlation among two or more constructs (Daoud, 2017). As recommended by Hair et al. (2014), this research utilised variance inflation factor (VIF) to assess for multi-collinearity. The recommended VIF level should be less than 5.0. Based on the results, the VIF values were all below the threshold of 5.0, implying that no collinearity issues were found in this study.

\section{Structural Model}

Findings for the six exogenous variables' influence on the endogenous variable, halal food new product adoption intention, is depicted in Table 3. The hypothesis was based on one-tailed t value of 1.65 and p-value of $<0.5$ (Hair, Ringle, \& Sarstedt, 2011). Results showed that among the TPB dimensions, subjective norm did not significantly affect halal food new product adoption intention. The $R^{2}$ value was 0.55 , while the $Q^{2}$ values were all above 0 (Hair et al., 2019). This suggests that the proposed model is acceptable. 
INTERNATIONAL JOURNAL OF ACADEMIC RESEARCH IN BUSINESS AND SOCIAL SCIENCES Vol. 10, No. 5, May, 2020, E-ISSN: 2222-6990 @ 2020 HRMARS

Table 3: Hypothesis testing results

\begin{tabular}{|l|l|l|l|l|}
\hline Hypothesis & $\begin{array}{l}\text { Standard } \\
\text { deviation }\end{array}$ & T-statistics & P-value & Decision \\
\hline H1. ATT>PAI & 0.040 & 1.943 & 0.026 & Accepted \\
\hline H2. SN $>$ PAI & 0.044 & 1.552 & 0.610 & Rejected \\
\hline H3. PBC>PAI & 0.058 & 3.031 & 0.001 & Accepted \\
\hline H4. HLOG $>$ PAI & 0.058 & 3.970 & 0 & Accepted \\
\hline H5. HC>PAI & 0.055 & 3.621 & 0 & Accepted \\
\hline H6. PRO $>$ PAI & 0.061 & 4.368 & 0 & Accepted \\
\hline
\end{tabular}

Note: Halal Food Product New Adoption Intention (PAI); Attitude (AT); Subjective Norm (SN);

Perceived Behavioural Control (PBC); Halal Certification (HLOG); Health Consciousness (HC); and

Promotion (PRO).

\section{Conclusion}

This investigation extended the TPB by studying the determinants of halal food new product adoption intention in Malaysia. The study has shown that consumers' perceptions are different concerning halal food new product adoption intention compared to normal consumption. Hence, consumers who are not experienced with certain products will rely on the investigated factors. This study showed significant results between halal food new product adoption intention and all its determinants, except subjective norm. These results are supported by Bashir et al. (2018), who have assessed halal purchase intention determinants amongst non-South Africans. They reported that subjective norm had no significant effect on halal purchase intention. Similarly, Vanany et al. (2019) determined that subjective norm did not have a significant role in predicting the intention to consume halal food in Indonesia.

In summary, understanding halal food new product adoption intention and its antecedents are crucial for any business that aims to launch new products into the market or willing to compete in this market. Without a proper strategy, the business strives to attract consumers to adopt thier products. Afendi et al. (2014) have mentioned that for businesses to achieve sustainable future growth, they must understand how consumers' intention towards purchase behaviour is determined. Therefore, this study has provided businesses with a fresh perspective of how to entice consumers to adopt products. The results have indicated that five out of six factors aid businesses in attracting consumers to adopt new halal food products.

\section{References}

Abdul, M., Ismail, H., Hashim, H., \& Johari, J. (2009). Consumer decision making process in shopping for halal food in Malaysia. China-USA Business Review, 8(9), 40-48.

Afendi, N. A., Azizan, F. L., \& Darami, A. I. (2014). Determinants of halal purchase intention: case in Perlis. International Journal of Business and Social Research, 4(5), 118-123.

Ajzen, I. (1985). From intention to action: a theory of planned behavior. in Kuhl, J. and Beckman, J. (Eds). Action Control: From Cognition to Behavior. New York: Springer.

Alam, S. S., \& Sayuti, N. M. (2011). Applying the Theory of Planned Behavior (TPB) in halal food purchasing. International Journal of Commerce and Management, 21(1), 8-20. 
INTERNATIONAL JOURNAL OF ACADEMIC RESEARCH IN BUSINESS AND SOCIAL SCIENCES

Vol. 10, No. 5, May, 2020, E-ISSN: 2222-6990 @ 2020 HRMARS

Alansi, A., Olya, H. G. T., \& Han, H. (2018). Effect of general risk on trust, satisfaction, and recommendation intention for halal food. International Journal of Hospitality Management, 83(october), 210-219.

Ali, A., Xiaoling, G., Sherwani, M., \& Ali, A. (2017). Factors affecting halal meat purchase intentionevidence from international Muslim students in China. British Food Journal, 119(3), 527-541.

Ali, A., Xiaoloing, G., Sherwani, M., \& Ali, A. (2018). Antecedents of consumers' Halal brand purchase intention: an integrated approach. Management Decision, 56(4), 715-735.

Al-Swidi, A., Huque, S. M. R., Hafeez, M. H., \& Shariff, M. N. M. (2014). The role of subjective norms in theory of planned behavior in the context of organic food consumption. British Food Journal, 116(10), 1561-1580.

Arsil, P., Tey, Y. S., Brindal, M., Phua, C. U., \& Liana, D. (2018). Personal values underlying halal food consumption: evidence from Indonesia and Malaysia. British Food Journal, 120(11), 2524-2538.

Atulkar, S., \& Kesari, B. (2017). Satisfaction, loyalty and repatronage intentions: Role of hedonic shopping values. Journal of Retailing and Consumer Services, 39(November), 23-34.

Awan, H. M., Siddiquei, A. N., \& Haider, Z. (2015). Factors affecting Halal purchase intention evidence from Pakistan's Halal food sector. Management Research Review, 38(6), 640-660.

Aziz, Y. A., \& Chok, N. V. (2013). The role of Halal awareness, Halal certification, and marketing components in determining Halal purchase intention among non-Muslims in Malaysia: A structural equation modelling approach. Journal of International Food \& Agribusiness Marketing, 25(1), 1-23.

Babakus, E., \& Mangold, W. G. (1992). Adapting the SERVQUAL scale to hospital services: an empirical investigation. Health Services Research, 26(6), 767-786.

Bashir, K. M. I., Kim, J., Mohibbullah, M., Sohn, J. H., \& Choi, J. (2018). Strategies for improving the competitiveness of Korean seafood companies in overseas halal food market. Journal of Islamic Marketing, 10(2), 606-632.

Bonne, K., Vermeir, I., \& Verbeke, W. (2008). Impact of religion on Halal meat consumption decision making in Belguim. Journal of International Food \& Agribusiness Marketing, 21(1), 5-26.

Boyd, K. T. (1972). Product testing. Journal of the royal statistical society, 21(3), 151-159.

Chuah, S. H., Marimuthu, M., Kandampully, J., \& Bilgihan, A. (2017). What drives Gen Y loyalty? Understanding the mediated moderating roles of switching costs and alternative attractiveness in the value-satisfaction-loyalty chain. Journal of Retailing and Consumer Services, 36(May 2017), 124-136.

Daoud, J. (2017). Multicollinearity and Regression Analysis. Journal of Physics: Conference Series, 949, 1-6.

Elseidi, R. I. (2018). Determinants of halal purchasing intentions: evidences from UK. Journal of Islamic Marketing, 9(1), 167-190.

Hair, J. F., Sarstedt, M., Hopkins, L., \& Kuppelwieser, V. G. (2014). Partial least square structural equation modelling (PLS-SEM) An emerging tool in business research. European Business Review, 26(2), 106-121.

Hair, J. F., Risher, J. J., Sarstedt, M., \& Ringle, C. M. (2019). When to use and how to report the results of PLS-SEM Article information. European Business Review, 31(1), 2-24.

Hair, J. F., Ringle, C. M., \& Sarsedt, M. (2011). PLS-SEM: indeed a silver bullet. Journal of Marketing Theory and Practice, 19(2), 139-151. 
INTERNATIONAL JOURNAL OF ACADEMIC RESEARCH IN BUSINESS AND SOCIAL SCIENCES

Vol. 10, No. 5, May, 2020, E-ISSN: 2222-6990 @ 2020 HRMARS

Hakeem, A., \& Lee, H. (2018). Understanding Muslim visitors ' attitudes towards Korean street food Understanding Muslim visitors ' attitudes towards Korean. International Journal of Tourism Sciences, 18(3), 215-235.

Haque, A., Sarwar, A., Yasmin, F., Tarofder, A. K., \& Hossain, M. A. (2015). Non-Muslim consumer's perception toward purchasing Halal food products in Malaysia. Journal of Islamic Marketing, 6(1), 133-147.

Henseler, J., Ringle, C., \& Sarstedt, M. (2015). A New Criterion for Assessing Discriminant Validity in Variance-based Structural Equation Modeling. Journal of the Academy of Makerting Science, 43, 115-135.

Henseler, J., Ringle, C., \& Sinkovics, R. (2009). The use of Partial least squares path modelling in international marketing. in Sinkovics, R., \& Ghauri, P. (Eds.). New Challenges to International Marketing : Advances in International Marketing(pp.277-319). Emerald Group.

Hussain, I., Rahman, S., Zaheer, A., \& Saleem, S. (2016). Integrating factors influencing consumers' Halal products purchase: Application of theory of Reasoned Action. Journal of International Food \& Agribusiness Marketing, 28(1), 35-58.

Jain, S., Khan, M. N., \& Mishra, S. (2017). Understanding consumer behavior regarding luxury fashion goods in India based on the theory of planned behavior. Journal of Asia Business Studies, 11(1), 4-21.

Karoui, S., \& Khemakhem, R. (2019). Factors affecting the Islamic purchasing behavior- a qualitative study. Journal of Islamic Marketing, 10(4), 1104-1127.

Khalek, A. A., \& Ismail, S. H. S. (2015). Why are we eating halal - using the theory of planned behavior in predicting halal food consumption among generation $\mathrm{Y}$ in Malaysia. International Journal of Social Science and Humanity, 5(7), 608-612.

Khalek, A. A. (2014). Young Consumers' Attitude towards Halal Food Outlets and JAKIM's Halal Certification in Malaysia. Procedia - Social and Behavioral Sciences, 121, 26-34

Khan, A., \& Azam, M. K. (2016). Factors Influencing Halal Products Purchase Intention In India: Preliminary Investigation. IUP Journal of Marketing Management, 15, 20-35.

Kotler, P., \& Keller, K.L. (2012). Marketing Management $\left(14^{\text {th }}\right.$ ed). Pearson.

Lada, S., Tanakinjal, G. H., \& Amin, H. (2009). Predicting intention to choose halal products using theory of reasoned action. International Journal of Islamic and Middle Eastern Finance and Management, 2(1), 66-76.

Marmaya, N. H., Zakaria, Z., \& Desa, M. N. M. (2019). Gen Y consumers' intention to purchase halal food in Malaysia: a PLS-SEM approach. Journal of Islamic Marketing, 10(3), 1003-1014.

Mukhtar, A., \& Butt, M. M. (2012). Intention to choose halal products: the role of religiosity. Journal of Islamic Marketing, 3(2), 108-120.

Ngah, A. H., Zainuddin, Y., \& Thurasamy, R. (2017). Applying the TOE framework in the Halal warehouse adoption study. Journal of Islamic Accounting and Business Research, 8(2), 161-181.

Rachbini, W. (2018). The Relationship of Attitude, Subjective Norm, Perceived Behavioral Control on Halal Food Purchasing Behavior in Jakarta. Journal of Business and Management, 20(1), 28-37.

Rahim, N. A., \& Junos, S. (2012). The Halal Product Acceptance Model for the Religious Society. Business \& Management Quarterly Review, 3(1), 17-25.

Rezai, G., Mohamed, Z., \& Shamsudin, M. N. (2012). Non-Muslim consumer's understanding of Halal principles in Malaysia. Journal of Islamic Marketing, 3(1), 35-46. 
INTERNATIONAL JOURNAL OF ACADEMIC RESEARCH IN BUSINESS AND SOCIAL SCIENCES

Vol. 10, No. 5, May, 2020, E-ISSN: 2222-6990 @ 2020 HRMARS

Said, M., Hassan, F., Musa, R., \& Rahman, N. A. (2014). Assessing Consumers ' Perception, Knowledge and Religiosity on Malaysia's Halal Food Products. Procedia - Social and Behavioral Sciences, 130, 120-128.

Sherwani, M., Ali, A., Ali, A., \& Hussain, S. (2018). Determinants of halal meat consumption in Germany. Journal of Islamic Marketing, 9(4), 863-883.

Sun, K., Zuo, M., \& Kong, D. (2016). What and how affect influence the consequence of product adoption. Pacific Asia Conference on Information Systems, PACIS 2016 - Proceedings, 280.

Talib, M. S. A., Sawari, S. S. M., Hamid, A. B. A., \& Ai Chin, T. (2016b). Emerging Halal food market: an institutional theory of Halal certificate implementation. Management Research Review, 39(9), 987-997.

Vanany, I., Soon, J. M., Maryani, A., \& Wibawa, B. M. (2019). Determinants of halal-food consumption in indonesia. Journal of Islamic Marketing. 11(2), 507-521.

Weng, J. T., \& Run, E. C. (2013). Consumer's personal values and sales promotion preferences effect on behavioural intention and purchase satisfaction for consumer product. Asia Pacific Journal of Marketing and Logistics, 25(1), 70-101.

Yang, H., Lee, H., \& Zo, H. (2017). Indusadoption Management \& Data Systems Article information : User acceptance of smart home services : An extension of the theory of planned behavior. Indusadoption Management and Data Systems, 117(1), 68-89.

Yasanallah, P., \& Vahid, B. (2012). Studying the Status of Marketing Mix (7Ps) in Consumer Cooperatives at llam Province from Members' Perspectives. American Journal of Indusadoption and Business Management, 02(04), 194-199.

Zakaria, Z. M., Majid, M. D. A. Z., Ahmad, Z., Jusoh, Z., \& Zakaria, N. Z. (2017). Influence of Halal certification on customers' purchase intention. Journal of Fundamental and Applied Sciences, 9(5s), 772-787. 